\title{
New Records for a Bad Weed
}

\section{By Keith Best and Archie Budd, Swift Current}

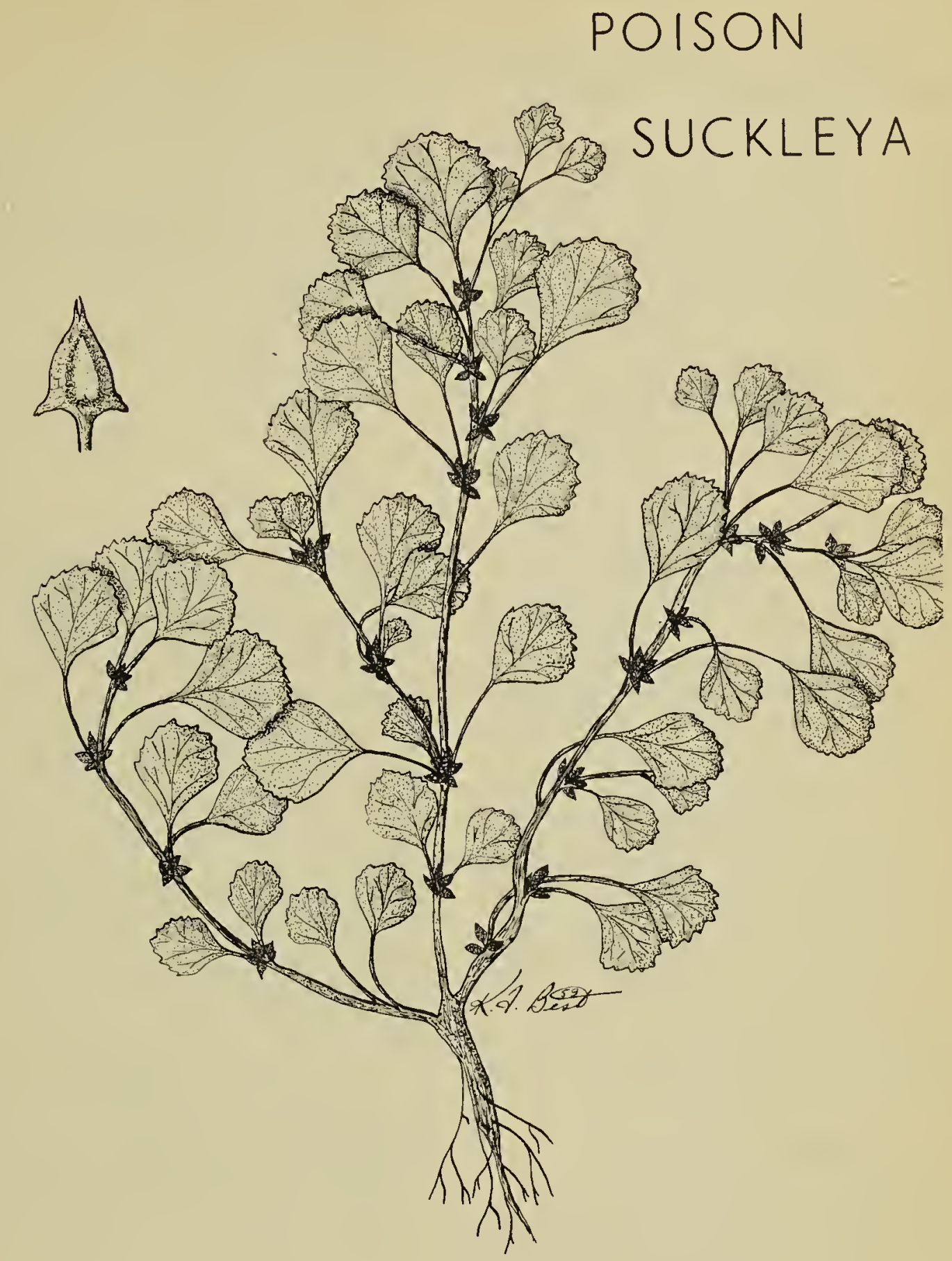

POISON SUCKLEYA (Suckleya suckleyana (Torr.) Rydb.) is an annual herb of the Chenopodiaceae or Goosefoot family, and is a native of the drier plains of Colorado, Montana, North Dakota and southern Saskatchewan. It is generally found along streams, slough margins and dried water-holes but is rare in Saskatchewan. It is poisonous to cattle and sheep due to its content of hydrocyanic acid.

The plant is generally of a somewhat prostrate habit, with stout much-branched succulent stems, often grooved and scurfy. The stems grow to a length of 12 inches or so and bear stalked, alternate leaves, of a round or sometimes diamond shape and up to an inch in length. The leaves are irregularly blunt-toothed along the upper margins.

The flowers are unisexual, the male flowers being in the axis of the upper leaves, whilst the pistillate flowers are in the lower leaf axils. The pistillate flowers are enclosed in a couple of stiff winged bracts and the fruit is from $3 / 8$ to $1 / 4$ inch long, with an abruptly-pointed end.

This plant was found near Moose Jaw by Mr. Neil Gilmour, Weed Inspector, and has recently been found at Success, near Swift Current, and also near Vantage and Tuxford. 